\title{
Molecular Typing and Drug Resistance Patterns of Staphylococcus aureus Isolated From Raw Beef and Chicken Meat Samples
}

\author{
Samaneh Farahmand ${ }^{1}$, Mehri Haeili ${ }^{1 *}$, Davood Darban-Sarokhalil ${ }^{2}$
}

1. Department of Animal Biology, Faculty of Natural Sciences, University of Tabriz, Tabriz, Iran

2. Department of Microbiology, School of Medicine, Iran University of Medical Sciences, Tehran, Iran

\section{ABSTRACT}

Background: Staphylococcus aureus is one of the most important food-borne pathogens. The objective of this study was to determine the prevalence, molecular types and drug resistance pattern of $S$. aureus isolated from retail meat in Tabriz city.

Materials \& Methods: 60 raw meat samples (chicken and beef) were taken from different markets and were inoculated in selective Mueller Hinton broth media supplemented with $10 \% \mathrm{NaCl}$. Identification of $\mathrm{S}$. aureus isolates was performed using conventional biochemical tests. Susceptibility to different antibiotics and genotypes of isolates were determined by disc diffusion and spa typing methods respectively.

Results: Fifteen S. aureus strains were isolated from 60 different meat samples which belonged to spa types $\mathrm{t} 14870, \mathrm{t} 3802$, $\mathrm{t} 1814, \mathrm{t} 491, \mathrm{t} 386, \mathrm{t} 3424$ and spa type $\mathrm{t} 14870$ with the frequency of $33.3 \%$ was the most prevalent genotype among $\mathrm{S}$. aureus isolates. spa types of three isolates were not found in Ridom Spa Server data base and were considered as novel types. About $46.6 \%$ of isolates were resistant to more than one antibiotic and $13.3 \%$ of isolates were identified as methicillin resistant $S$. aureus (MRSA). Tigecycline, imipenem and ceftaroline were found to be the most effective agents against $S$. aureus isolates.

Conclusion: Oure results revealed a $25 \%$ contamination rate with S. aureus. Most of the molecular types of isolates were found to be linked to human infections. High rate of antibiotic resistance was observed among the isolates which poses a great threat to public health.

Keywords: Staphylococcus aureus, MRSA, spa typing, Meat, Antibiotic resistance

Received: 2020/05/07; Accepted: 2020/08/17; Published Online: 2020/09/26

\begin{tabular}{|c|c|}
\hline Corresponding Information: & $\begin{array}{l}\text { Mehri Haeili, Department of Animal Biology, Faculty of Natural Sciences, University of Tabriz, Tabriz, Iran. } \\
\text { Email: m.haeili@ tabrizu.ac.ir }\end{array}$ \\
\hline (ख) $\theta$ & $\begin{array}{l}\text { This is an original open-access article distributed under the terms of the Creative Commons Attribution-noncommercial } 4.0 \text { International License which } \\
\text { distribution of the material just in noncommercial usages with proper citation. }\end{array}$ \\
\hline
\end{tabular}

Use your device to scan and read the article online

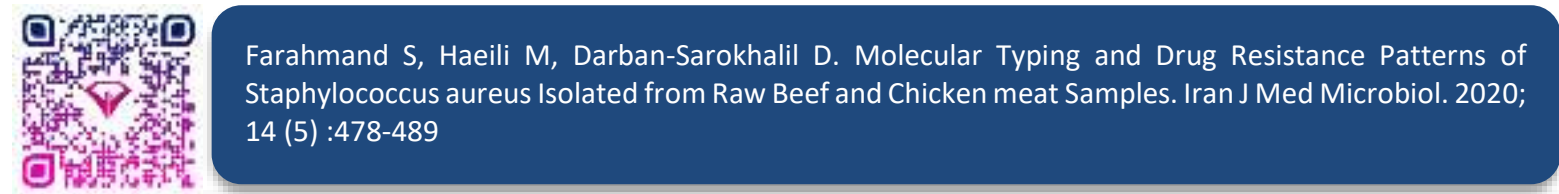

Download citation: BibTeX | RIS | EndNote | Medlars | ProCite | Reference Manager | RefWorks
Send citation to:
$\otimes$ Mendeley
2 Zotero
RefWorks

\section{Introduction}

Staphylococcus aureus is one of the most important foodborne pathogens and the most common causes of food poisoning (1). This bacterium is known in many countries as the third leading cause of foodborne illnesses after Salmonella and Vibrio parahaemolyticus (2). Milk, dairy products and meat are some of the foods associated with staphylococcal food poisoning [1]. This bacterium multiplies quickly at room temperature and secretes its heat-resistant enterotoxins, causing food poisoning following consumption of foods contaminated with these toxins. S. aureus is also a cause of various diseases in humans such as skin and soft tissue infections, bacteremia and pneumonia and is a serious problem in hospitals and the food industry (3). The pathogenicity of 
S. aureus is mediated by the bacterial specific structure and extracellular secretions such as various toxins. In recent decades, the widespread use of antibiotics has led to the emergence of multidrug-resistant (MDR) bacterial strains. S. aureus has a high adaptive capacity to varying environmental conditions and quickly becomes resistant to virtually all antibiotics (4). Recently, MDR strains of $S$. aureus have been frequently reported from food poisoning outbreaks and isolated from various food products $(3,5,6)$. In particular, isolation of methicillinresistant $S$. aureus (MRSA) from meat products raises concerns that these contaminated meats may be a means of transmitting MRSA to human communities (7). The term livestock-associated MRSA (LA-MRSA) is used to differentiate methicillin-resistant $S$. aureus of human origin (acquired from hospital or community) from those isolated from livestock. LA-MRSA strains have the potential to cause disease in humans and often show multidrug resistance profiles (8). Genotyping of microbial strains is important to understand how bacteria spread, to find a possible source of infection, and to identify the dominant types. There are several molecular methods for typing of $S$. aureus and MRSA strains. These methods include DNA fingerprinting by PFGE, SCC mec typing and sequencing-based methods such as spa-typing and MLST $(3,9)$. In spa typing, the polymorphism of $x$-region of the spa gene (encoding surface protein A) is examined by $P C R$ and sequencing. Because $x$-region has high degrees of polymorphism, it can be used in genotyping studies. The discriminatory power of spa typing method is lower than PFGE and higher than MLST. This method is more costeffective than methods such as MLST that require sequencing of at least 7 genes, or the PFGE method $(10,11)$.

Since meat and meat products are known as important reservoirs of $S$. aureus and have been involved in various outbreaks, the aim of this study was to investigate the contamination rate of meat samples collected from different parts of Tabriz city with S. aureus and to determine the drug resistance pattern and genotypes of obtained isolates.

\section{Materials and Methods}

\section{Isolation of $S$. aureus from meat samples}

Raw beef and chicken samples were collected from various meat shops in Tabriz from June 2019 to January 2020. For sampling, 10 grams of meat sample was taken and placed in sterile tubes containing Mueller-Hinton broth supplemented with $10 \% \mathrm{NaCl}$. The tubes were transferred to the laboratory at cold temperature and placed in an incubator at $37^{\circ} \mathrm{C}$ for 24 hours. Then, different dilutions were prepared and 10 to $20 \mu \mathrm{L}$ of each dilution was transferred to mannitol salt agar medium and placed at $37^{\circ} \mathrm{C}$ for 24 hours. Colonies with yellow halo on mannitol salt agar medium were selected and after purification on nutrient agar medium were subjected for identification by microscopic observation and conventional biochemical methods (catalase, coagulase and DNase tests).

\section{Antimicrobial Susceptibility Testing}

For this purpose, disk diffusion was performed by Kirby Bauer method and using paper disks containing the following antibiotics: ampicillin, ceftaroline, imipenem, levofloxacin, ciprofloxacin, sulfamethoxazole-trimethoprim (BBL Sensi-Disc ${ }^{\mathrm{T}}$, MD, BBL) and tigecycline (Mast Co, Merseyside, UK). Interpretation of disk diffusion results was performed according to the Clinical \& Laboratory Standards Institute (CLSI) (12). Interpretation of the results for tigecycline was performed using FDA guidelines, according to which bacteria with an inhibition zone diameter of 19 $\mathrm{mm}$ and more were considered susceptible to tigecycline.

Identification of Methicillin-Resistant Strains of Staphylococcus aureus

Two phenotypic and genotypic methods were used to identify MRSA strains. In the phenotypic method, the susceptibility of the studied isolates to cefoxitin $30 \mu \mathrm{g}$ (BBL Sensi-Disc TM, Becton - Dickinson, Sparks, MD) was evaluated by disk diffusion method. Strains with an inhibition zone diameter of $21 \mathrm{~mm}$ or less were considered as cefoxitin resistant and categorized as MRSA. In the genotypic method, detection of mecA and mecC genes was performed by PCR method using primers listed in Table 1.

Determination of Molecular types of $S$. aureus Isolates by spa Typing Method

DNA extraction was performed by boiling method as follows; a loop full of bacterial colonies grown on the nutrient agar medium was dissolved in $950 \mu \mathrm{L}$ of PBS buffer. The tubes were centrifuged for 10 minutes at $7000 \mathrm{rpm}$. The precipitate was dissolved in $200 \mu$ l of sterile TE buffer (1x) and boiled for 10 minutes. After centrifugation at 13,000 rpm for 20 minutes, the supernatant was transferred to another container and 1:10 dilution of supernatant was used as DNA template in PCR reaction (https: // www. eurlar.eu/CustomerData/Files/Folders/21-protocols/278_mcrmultiplex-pcr-protocol-v2-oct16.pdf).

To amplify the spa gene, PCR was performed in a final volume of $50 \mu \mathrm{L}$ containing $25 \mu \mathrm{L}$ of Taq DNA Polymerase Master Mix Red solution (Ampliqon, Denmark), $2.8 \mu \mathrm{L}$ of each of the reverse and forward primers (Table 1), $17.4 \mu \mathrm{L}$ of distilled water, $2 \mu \mathrm{L}$ of template DNA and according to the following program:

One cycle at $95^{\circ} \mathrm{C}$ for 10 minutes (First denaturation), 30 cycles including $1-95^{\circ} \mathrm{C}$ for 30 seconds (Denaturation), $2-58^{\circ} \mathrm{C}$ for 45 seconds (Annealing), 3$72^{\circ} \mathrm{C}$ for 45 seconds (Extension), and final extension at $72^{\circ} \mathrm{C}$ for 10 minutes. The sequences of PCR products were determined by Codon company and analyzed by ChromasPro software. Isolates were assigned to 
particular spa types using the spa typing website ((http://www.spaserver.ridom.de).

Table 1. Nucleotide sequences of primers used in PCR reaction

\begin{tabular}{|c|c|c|c|}
\hline $\begin{array}{l}\text { Primer } \\
\text { name }\end{array}$ & Sequence $\left(5^{\prime}\right.$ to $\left.3^{\prime}\right)$ & Size of product (bp) & Reference \\
\hline $\begin{array}{l}\text { MecA-F } \\
\text { MecA-R }\end{array}$ & $\begin{array}{l}\text { TGGCTCAGGTACTGCTATCCAC } \\
\text { AGTTCTGCAGTACCGGATTTGC }\end{array}$ & 777 & This study \\
\hline $\begin{array}{l}\text { MecC-F } \\
\text { MecC-R }\end{array}$ & $\begin{array}{l}\text { GAAAAAAAGGCTTAGAACGCCTC } \\
\text { TGGCTCCTAATGCTAATGCAATG }\end{array}$ & 594 & This study \\
\hline $\begin{array}{l}\text { spa-1113f } \\
\text { spa-1514r }\end{array}$ & $\begin{array}{l}\text { TAAAGACGATCCTTCGGTGAGC } \\
\text { CAGCAGTAGTGCCGTTTGCTT }\end{array}$ & Variable & {$[11]$} \\
\hline
\end{tabular}

\section{Results}

Determination of the Frequency and Drug Susceptibility of $S$. aureus Isolated from Meat Samples

A total of 60 raw meat samples (chicken (18 samples) and beef (42 samples)) were collected from meat markets in Tabriz during the study period. Fifteen isolates (25\%) were obtained from these samples which were identified as $S$. aureus being observed as Grampositive cocci with grape-like cluster arrangement under microscopic examination and being positive for catalase, coagulase and DNase tests. The contamination rates in chicken and beef samples were $27.7 \%$ and $23.8 \%$, respectively. All isolates were evaluated for multi-drug resistance phenotype, the results of which are shown in Table 2 . According to drug susceptibility testing results, all isolates (100\%) were susceptible to imipenem, tigecycline and ceftaroline. The observed resistance rate to ampicillin, cefoxitin, quinolones and sulfamethoxazole-trimethoprim were $100 \%, 13.3 \%, 33.3 \%$ and $20 \%$, respectively.

\section{Identification of Methicillin-resistant S. aureus Isolates}

MRSA isolates were identified by disk diffusion (cefoxitin disk) and PCR methods (detection of mecA/C gene). Among $15 \mathrm{~S}$. aureus isolates obtained from meat samples, two were resistant to cefoxitin (with halo diameters of 17 and $19 \mathrm{~mm}$ ) and harbored mecA gene. The mecC gene was not detected in any of the isolates.

Determination of Molecular Types of $S$. aureus Isolates by spa Typing Method

For all isolates identified as $S$. aureus by phenotypic methods, PCR for spa gene was performed using specific primers. Types $\mathrm{t} 14870$ and $\mathrm{t} 3802$ were the most abundant spa types observed in five (33.3\%) and two $(13.3 \%)$ isolates respectively. spa types of three isolates were not detected in the database and were considered as new types. Also, in terms of distribution of molecular types among different meat samples, t14870, which was the most common spa type was found in $40 \%$ and $30 \%$ of chicken and beef isolates, respectively. While multidrug resistance phenotype was observed in three of five isolates belonging to t14870 type (60\%), the strains belonging to t3802 type (the second most common type) were associated with single drug resistance phenotype. Methicillin-resistant strains also belonged to spa types $\mathrm{t} 1814$ and $\mathrm{t} 386$, which were isolated from beef and chicken samples, respectively (Table 2).

Table 2. Genotype and drug susceptibility pattern of Staphylococcus aureus isolated from meat samples

\begin{tabular}{|c|c|c|c|}
\hline Isolate & spa type & Type of meat sample & Antimicrobial resistance profile \\
\hline SA1 & $\mathrm{t} 14870$ & Chicken & AM, CIP, LVX \\
\hline SA2 & New type & Beef & AM \\
\hline SA3 & $\mathrm{t} 3802$ & Chicken & AM, FOX \\
\hline SA4 & $\mathrm{t} 1814$ & Beef & AM, CIP, LVX,SXT \\
\hline SA5 & $\mathrm{t} 14870$ & Chicken & AM, CIP, LVX,SXT \\
\hline SA6 & $\mathrm{t} 14870$ & Beef & AM \\
\hline SA7 & $\mathrm{t} 491$ & Beef & AM \\
\hline SA & New type & Chicken & AM \\
\hline SA & $\mathrm{t} 3802$ & Beef & \\
\hline
\end{tabular}




\begin{tabular}{|c|c|c|c|}
\hline Isolate & spa type & Type of meat sample & Antimicrobial resistance profile \\
\hline SA10 & New type & Beef & AM \\
\hline SA11 & t386 & Chicken & AM,FOX \\
\hline SA12 & t14870 & Beef & AM \\
\hline SA13 & Non typeable & Beef & AM \\
\hline SA14 & t3424 & Beef & AM, CIP, LVX \\
\hline SA15 & t14870 & Beef & AM, CIP, LVX,SXT \\
\hline
\end{tabular}

CIP, ciprofloxacin; LVX, levofloxacin; SXT, trimethoprim/sulphamethoxazole; AM, ampicillin; FOX, cefoxitin;

\section{Discussion}

Improper use of human antibiotics in agriculture as a growth promoter or as a prophylactic agent with a dose lower than the treatment dose causes selective pressure on the bacterial populations living in the intestines of animals and the development of resistance. These resistant bacteria can be transmitted directly or indirectly to humans through animal products and cause disease in humans, or they can be a repository for the transmission of antibiotic resistance genes to human pathogenic bacteria $(13,14)$.

There are evidences supporting the transmission of extended-spectrum beta-lactamase (ESBL) producing Escherichia coli clones, from livestock to human being presumably through the food chains (15). Numerous studies have described the colonization of various animals with $S$. aureus, and methicillin resistant isolates have also been reported from food producing animals (16). In 2017, the World Health Organization recognized MRSA as one of the 12 families of bacteria that pose a serious threat to human health (17). In the present study, a $25 \%$ contamination rate with $S$. aureus $(27.7 \%$ chicken, $23.8 \%$ beef) was observed among meat samples collected from different parts of Tabriz city. The rate of contamination observed in this study was similar to the results of Ge et al., who reported a $S$. aureus contamination rate of $27.9 \%$ in meat samples studied in the United States (18). This rate of contamination is also lower than that reported by Tang et al., who described $S$. aureus contamination rate of $68 \%$ in meat samples from Denmark (19).

In the present study, $46.6 \%$ of the isolates were resistant to more than one antibiotic. Imipenem, tigecycline, and Ceftaroline fosamil were the most effective agents against $S$. aureus isolated from meat samples. In contrast, 100, 20 and $33 \%$ of isolates were resistant to ampicillin, sulfamethoxazoletrimethoprim and quinolones respectively. This amount of resistance observed against quinolones, as one of the most important antibiotics used for the treatment of upper respiratory and genitourinary tract infections, can be attributed to the widespread use of these antibiotics in farm animals.
In a study performed by Wu et al., who studied 1,850 raw meat samples and meat products from 39 cities in China, $35 \%$ of the samples were found to be contaminated with S. aureus. Only $1.26 \%$ of $S$. aureus isolates obtained from meat samples were sensitive to all 26 tested antibiotics, $94.6 \%$ were non-susceptible to more than 3 antibiotics and $12 \%$ of isolates showed resistance to more than 10 antibiotics (6). Xing et al., reported that $98.4 \%$ and $58.6 \%$ of the studied $S$. aureus were resistant to more than one and three antibiotics respectively (20).

We found methicillin-resistant bacteria in 10 and $20 \%$ of the isolates obtained from beef and chicken samples, respectively. Isolates SA4 and SA11 (13.3\%) belonging to spa types t1814 and t386 were classified as MRSA. Resistance to methicillin in these two strains was confirmed by both phenotypic and genotypic methods.

The frequency of MRSA observed in this study was higher than the values reported by Wu et al., in which $7.14 \%$ of $S$. aureus strains isolated from meat samples were identified as MRSA (6).

The prevalence of MRSA in meat samples varies in different geographical regions and rates of $1.9 \%$ in the United States, $0.5 \%$ in Korea, $13 \%$ in Denmark and $24.8 \%$ in Canada have been reported $(18,19,21,22)$.

The source of microbial contamination of meat can be endogenous originating from the animal microbiota or it can be exogenous, which is related to environmental pollutants and people involved in processing and transporting meat from slaughterhouses to meat markets. Using spa typing technique, type $\mathrm{t} 14870$ with a frequency of $33.3 \%$ was identified as the predominant spa type in $S$. aureus isolates obtained from meat samples being observed in $40 \%$ and $30 \%$ of chicken and beef isolates, respectively. In three of the five isolates belonging to this type $(60 \%)$ the multidrug resistance phenotype was observed, so that $80 \%$ of quinolones resistant isolates and all isolates resistant to sulfamethoxazole-trimethoprim belonged to type $\mathrm{t} 14870$. This type is one of the rare types in the world and there are few studies reporting detection of this genotype in human samples (23). Also, spa types t3802, 
t1814, t491 and t386 that were identified among the studied samples are common human types (24-26). Identification of common spa types of human infections among isolates obtained from meat samples in this study indicates that these contaminants are probably of human origin and therefore have the potential to be pathogenic in human. Also, 3 isolates characterized with new spa types that were not found in the Ridom spa Server database and were reported for the first time in the world. Drug susceptibility testing in these isolates revealed the single drug resistance phenotype (ampicillin resistance).

The high genetic diversity observed among the studied strains indicates that the clonal expansion was not occurred and the contaminating bacteria may have originated from various sources. Wu et al. reported ST1-t127 and ST7-t091as the two dominant spa types in $10.7 \%$ and $10.6 \%$ of $S$. aureus isolates obtained from meat samples, respectively (6). Narvaez et al. examined the prevalence of MRSA in meat samples from three pork factories in Canada. According to their results, most LA-MRSA isolates belonged to spa types t034 and t011. A 10\% resistance rate to tigecycline was observed and less than $3 \%$ of isolates were resistant to daptomycin, gentamicin and trimethoprim-sulfamethoxazole (22).
Overall, the results of this study showed a $25 \%$ contamination rate with $S$. aureus in raw meat samples and most of the identified molecular types were linked with human infections. Identification of MRSA as an important human pathogen, in meat samples is a serious threat to food safety as there is always a potential for these resistant isolates to easily spread across the country via food chain or direct contact. Reducing the agricultural use of important medical antibiotics such as quinolones and other families of antimicrobials in the farm animals can contribute to reduced resistance to these antibiotics. Therefore, proper control should be done on the consumption of antibiotics in food animals and food hygiene in different stages of their preparation (animal husbandry, slaughterhouse, packaging, etc.) to prevent the emergence and dissemination of drug resistant bacteria.

\section{Acknowledgment}

This study was supported by the University of Tabriz.

\section{Conflict of Interest}

Authors declared no conflict of interests.

\section{Conclusion}




$$
\begin{aligned}
& \text { مجله ميكروبشناسى يزشكى ايران }
\end{aligned}
$$

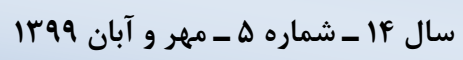

$$
\begin{aligned}
& \text { Journal homepage: www.ijmm.ir }
\end{aligned}
$$

تعيين تيبه هاى مولكولى و الكوهاى مقاومت آنتىبيو تيكى سويههاى استافيلوكوكوس اورئوس

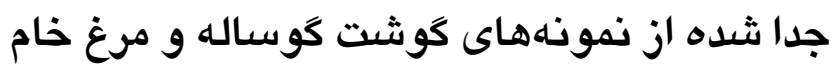

\section{سمانه فرهمند'، مهرى هائيلى ':، داوود دربان ساروخليل r}

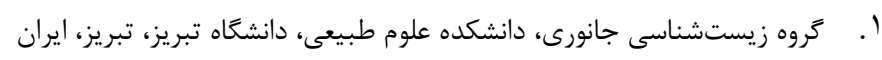

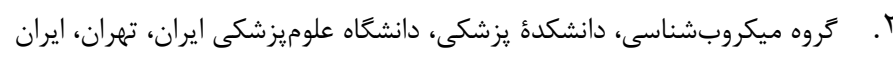

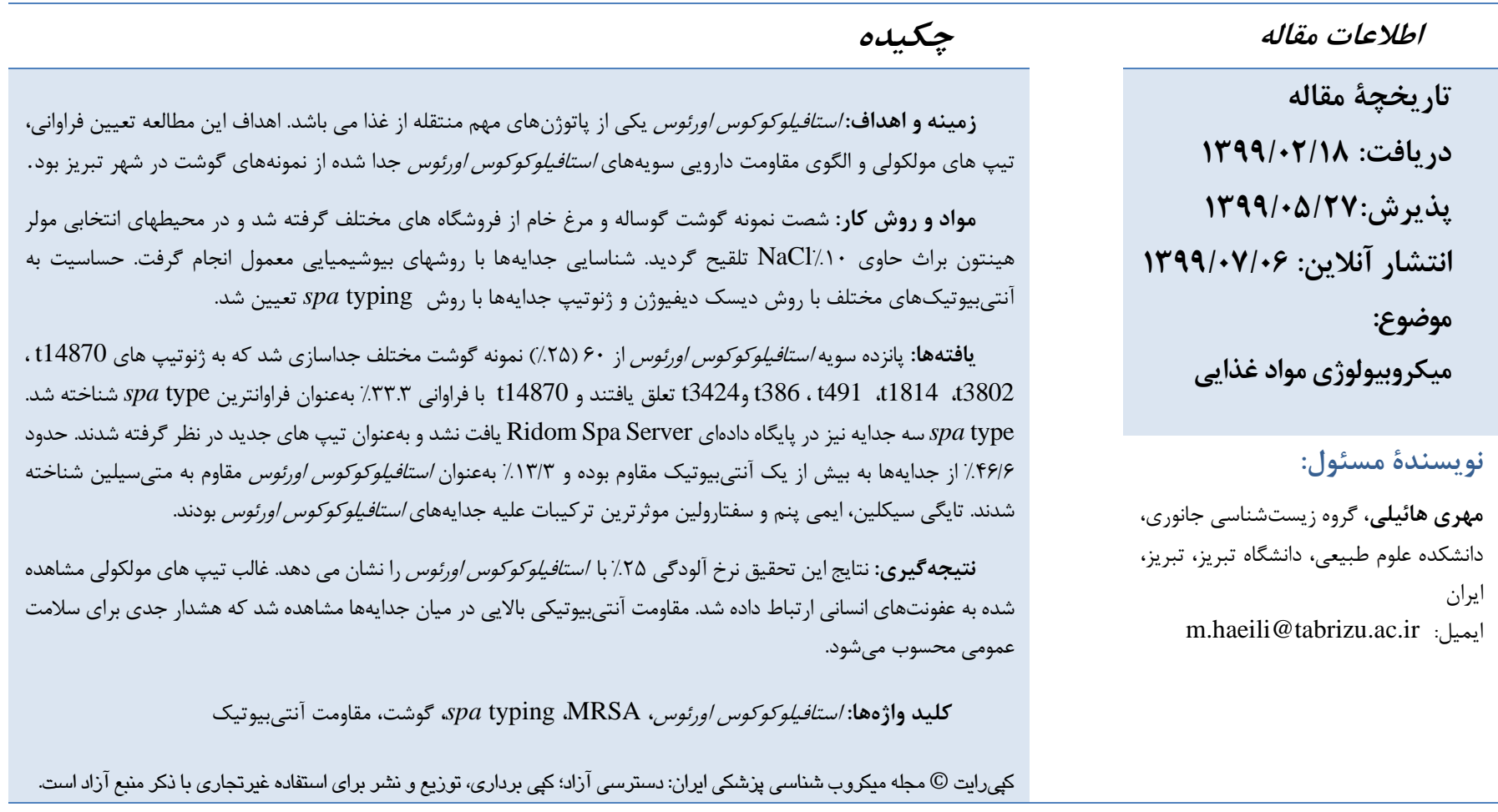

مقدمه

باكتريمى و ينومونى بوده و بdعنوان يك مشكل جدى در بيمارستانها

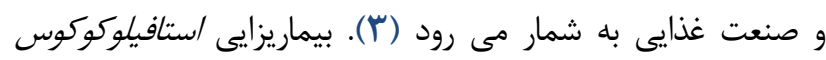
اورئوس توسط ساختار باكتريايى و ترشحات خارج سلولى مثل انواع توكسين ها ايجاد مىشود. در دهه هاى اخير استفاده گسترده از آنتىبيوتيكها عامل ظهور سويههاى باكتريايى مقاوم جند دارويى شده است. /ستافيلوكوكوس /ورئوس ظرفيت تطابق رذيرى بالايى به شرايط محيطى مختلف داشته و به سرعت به تقريبا تمامى آنتىبيوتيكها مقاوم مىشود (F). اخيرا سويههاى /ستافيلوكوكوس /ورئوس مقاوم به جند مند دارو مكررا از همه خيرىهاى ناشى از مسموميتهاى غذايى خزارش و از محصولات غذايى متعددى جداسازى شدهاند (س, ه, ؟). بهويزه
استافيلوكوكوس اورئوس يكى از ياتوزنهاى مههم منتقله از غذا

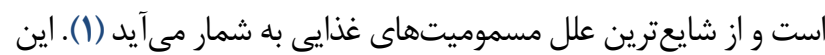
باكترى در بسيارى از كثورها بهعنوان سومين عامل بروز بيمارىهاى غذايى بعد از سالمونلا و ويبريو ياراهموليتيكوس شناخته شده است (؟).

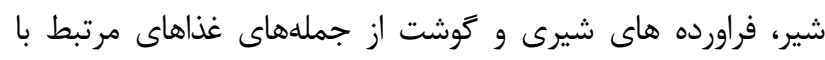
مسموميت استافيلوكوكوسى محسوب مىشوند (1). اين باكترى در دماى اتاق بلسرعت تكثير يافته و انتروتوكسينهاى مقاوم به حرارت

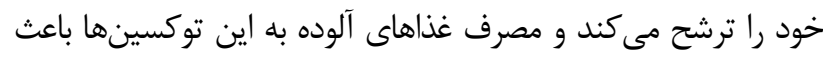
ايجاد مسموميت غذايى مىشود. استافيلوكوكوس اورئوس همجنين عامل بيمارىهاى مختلفى در انسان مثل عفونتهاى يوست و بافت نرم، 
داده شد. لولهها در دماى سرد به آزمايشگاه منتقل شده و به مدت Fr ساعت درون انكوباتور MV درجه سلسيوس قرار داده شدند. سيس رقتهاى مورد نظر تهيه شده و از هر رقت • • تا•ب ميكروليتر بر روى محيط مانيتول سالت آتار انتقال داده شد و به رهاه مدت FF ساعت در دماى TV درجه سلسيوس قرار داده شد. كلنىهاى داراى هاله زرد بر روى محيط مانيتول سالت آكار

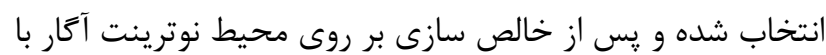
مشاهده ميكروسكويى و روشهاى بيوشيميايى مرسوم (تست هاى كاتالاز، كواگولاز و DNase) شناسايى شدند.

\section{تست حساسيت ضد ميكروبى}

بدين منظور ديسك ديفيوزن با روش Kirby Bauer و با استفاده از ديسك هاى كاغذى حاوى آنتىبيوتيكهاى آميىسيلين، سفتارولين، ايمىينم، لووفلوكساسين، سييروفلوكساسين، سولفامتو كسازول-ترىمتويريم، (BBL Sensi-Disc تايگى سايكلين (Mast Co, Merseyside, UK) انجام شد. تفسير نتايج روش انتشار از ديسك در مورد همه آنتىبيوتيكها به جز تايكى Clinical \& Laboratory سايكلين با توجه به استانداردهاى Standards Institute (CLSI) به تايكى سايكلين با استفاده از دستورالعمل سازمان FDA انجام شد كه بر اساس آن باكترىهايى با قطر هاله عدم رشد ـ 19 ميليمتر بهنوان حساس به تايكىىيكلين در نظر گرفته شدند.

\section{شناسايى سويههاى /ستافيلوكوكوس /ورئوس مقاوم به}

متى سيلين

جهت شناسايى سويههاى MRSA از دو روش فنوتيىى و زنوتييى استفاده شد. در روش فنوتييى حساسيت جدايههاى مورد

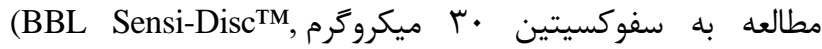
Becton-Dickinson, Sparks, MD) ارزيابى قرار ₹رفت. سويلهايى كه داراى قطر هاله عدم رشد I mm بودند بهعنوان سويههاى مقاوم به سفوكسيتين تلقى گرديده و بهعنوان mecA در نظر گرفته شدند. در روش زنوتييى رديابى زنهاى MRSA

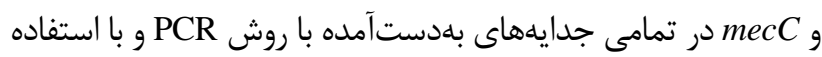
از يرايمرهاى ليست شده در جدول ا انجام گرفت.

تعيين تيبهاى مولكولى جدايههاى /ستافيلوكوكوس

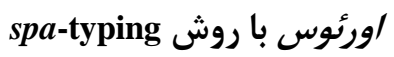

براى استخراج DNA براى واكنش PCR از روش جوشاندن به

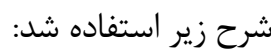

جداسازى استافيلوكوكوس /ورئوس مقاوم به متىسيلين از محصولات كوشتى (Methicillin Resistant S. aureus (MRSA)) اين نكرانى را ايجاد مى كند كه اين گوشتهاى آلوده وسيلهاى براى

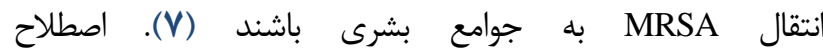
Livestock-Associated MRSA (LA-MRSA) حشام براى افتراق /ستافيلوكوكوس /ورئوس هاى مقاوم به متىسيلين

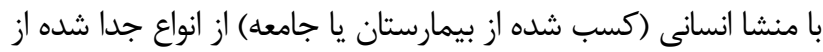

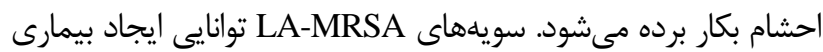
در انسان را داشته و غالبا مقاوم به جند دارو هستند (A). تيِبندى سويههاى ميكروبى براى يى بردن به نحوه انتشار

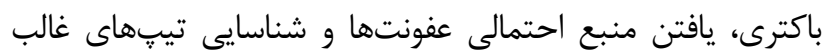
موجود بسيار حائز اهميت است. روشهاى مولكولى متعددى براى تيّ بندى و شناسايى سويههاى /ستافيلوكوكوس اورئوس و MRSA

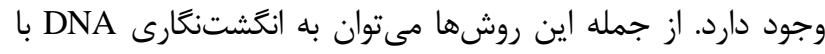

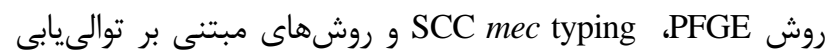
مانند و و spa-typing اشاره كرد (ب, 9). در روش spa typing ناحية x از رن spa (رمز كنندهى يروتئين سطحى A) با PCR گسترش يافته و توالى يابى مىشود. به دليل اينكه ناحية x داراى يلى مورفيسم بالايى است، مىتواند در بررسىهاى افتراقى و تيبِندى استفاده شود. اين روش در مقايسه با روش PFGE قدرت تمايز كمتر و نسبت به روش MLST قدرت تمايز بالاترى دارد. اين روش نسبت به روشهايى مثل MLST كه نياز به توالىيابى حداقلV زن دارد و يا روش PFGE مقرون بهصرفهتر است (•ا, (1). با توجه به

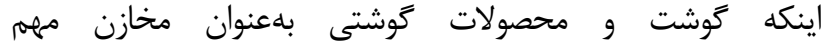
استافيلوكوكوس /ورئوس شناخته شده و در گسترش شيوع دخيل بودهاند، هدف از اين مطالعه، بررسى ميزان آلودگى نمونههاى گوشت جمعآورى شده از مناطق مختلف شهر تبريز، ايران با باكترى استافيلوكوكوس اورئوس و تعيين الكوى مقاومت دارويى و زنوتيب جدايههاى بdدست آمده بود.

$$
\text { روش يثروهش }
$$

\section{جداسازى سويههاى استافيلوكوكوس اورئوس از نمونه هاى كوشت}

نمونههاى گوشت كوساله و مرغ خام از فروشكاههاى گوشت

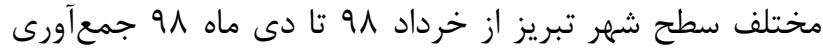

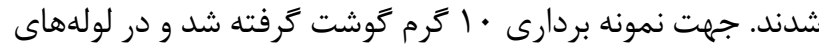

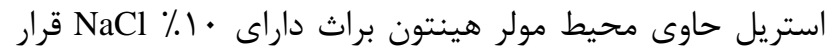


(جدول I)، V/F

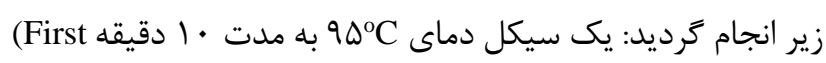
r . denaturation) ثانيه (Denaturation) ، ثانيه (Annealing)، (Extension)

.(Final Extension)

توالى محصولات PCR توسط شركت كدون تعيين و توسط

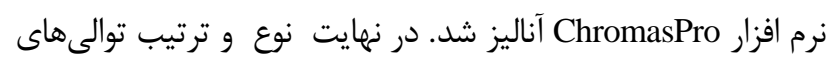
تكرارى در نتيجه مقايسه آنها با توالىهاى موجود در يايعاه دادهاى Ridom Spa Server
يك لوب ير از كلنى باكترى رشديافته روى محيط نوترينت

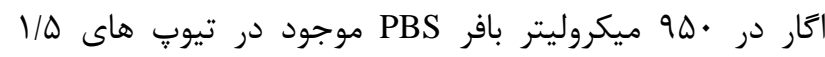

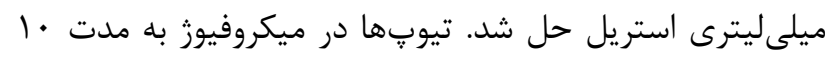

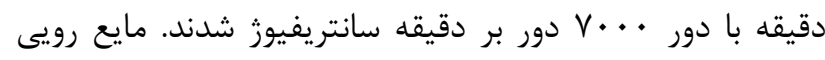

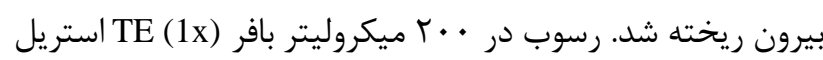

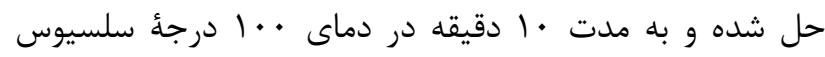

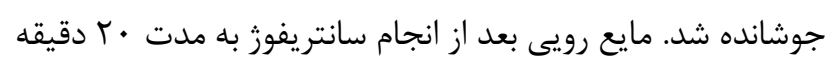

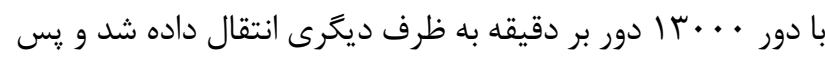

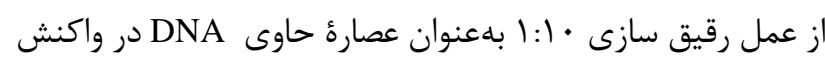

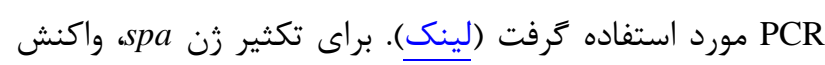
Taq در حجم نهايى •ض ميكروليتر حاوى DNA Polymerase Master Mix Red (Ampliqon,

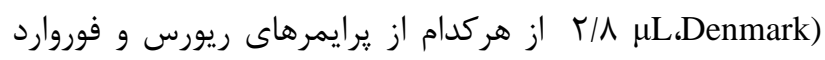

جدول 1. توالى نو كلئوتيدى يرايمرهاى مورد استفاده در واكنشPCR

\begin{tabular}{|c|c|c|c|}
\hline منبع & اندازه محصول(bp) & توالى(' 3 ' to ') & نام برايمر \\
\hline اين مطالعه & VVV & $\begin{array}{l}\text { TGGCTCAGGTACTGCTATCCAC } \\
\text { AGTTCTGCAGTACCGGATTTGC }\end{array}$ & $\begin{array}{l}\text { MecA-F } \\
\text { MecA-R }\end{array}$ \\
\hline اين مطالعه & $\Delta 9 F$ & $\begin{array}{l}\text { GAAAAAAAGGCTTAGAACGCCTC } \\
\text { TGGCTCCTAATGCTAATGCAATG }\end{array}$ & $\begin{array}{l}\text { MecC-F } \\
\text { MecC-R }\end{array}$ \\
\hline [11] & متغير & $\begin{array}{c}\text { TAAAGACGATCCTTCGGTGAGC } \\
\text { CAGCAGTAGTGCCGTTTGCTT }\end{array}$ & $\begin{array}{l}1113 \mathrm{f}-\mathrm{spa} \\
1514 \mathrm{r}-\mathrm{spa}\end{array}$ \\
\hline
\end{tabular}

بافتهها

شناسايى جدايههاى استافيلوكوكوس اورئوس مقاوم به متىسيلين

شناسايى جدايههاى /ستافيلوكوكوس /ورئوس مقاوم به

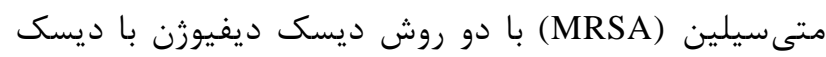
سفوكسيتين و رديابى زن mecA/C صورت گرفت. از ميان ها ها

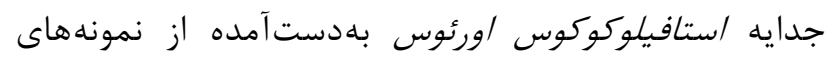
كوشت دو جدايه مقاوم به سفوكسيتين بوده (با قطر هاله هاى Vاو 9 او ميلى متر) و در هر دو جدايه زن

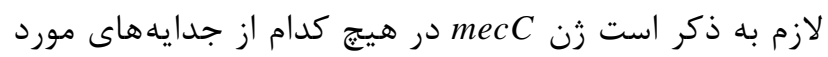
بررسى شناسايى نشد.

تعيين تيبهاى مولكولى جدايههاى استافيلوكوكوس اورئوس با روش spa typing

براى تمامى ايزولههايى كه در روش فنوتييى بلهنوان استافيلوكوكوس /ورئوس تعيين هويت شدند، PCR زن spa با استفاده از يرايمرهاى اختصاصى انجام گرفت. بر اساس نتايج بلدستوآمده

\section{تعيين فراوانى و حساسيت دارويى استافيلوكوكوس} اورئوس هاى جدا شده از نمونههاى كوشت

در مجموع •9 نمونه گوشت خام (كوشت مرغ (1) نمونه) و گوشت

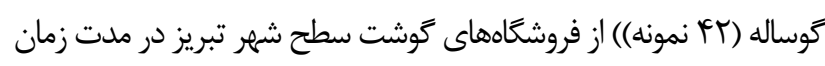

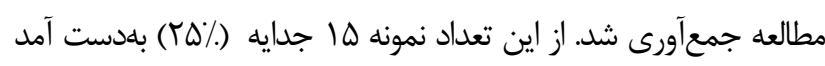
كه به صورت كوكوسهاى گرم مثبت با آرايش خوشه انكورى در بررسى ميكروسكوبى مشاهده شدند و داراى نتايج مثبت در تستهاى كاتالاز، كواگولاز و DNase بوده و بهعنوان/ستافيلوكوكوس /ورئوس شناسايى شدند.

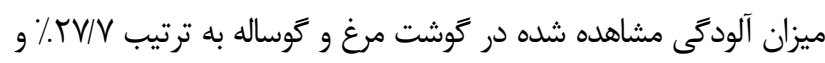

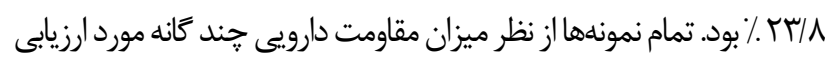

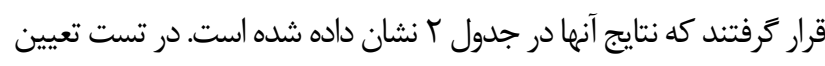
حساسيت دارويى تمامى جدايهها ( • (1.) به ايمى ينم، تايكى سايكلين و سفتارولين حساس بودند. ميزان مقاومت مشاهده شده عليه آميىسيلين،

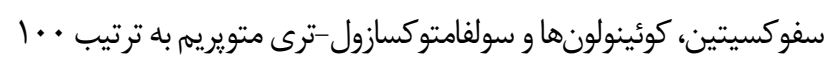

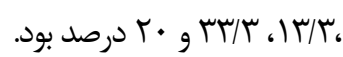




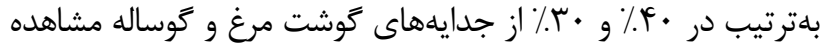
شد. درحالى كه در سه جدايه از ينج جدايه متعلق به تيت

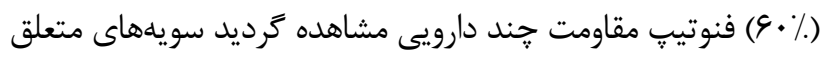

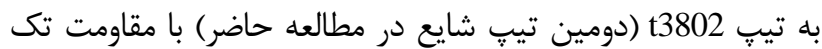

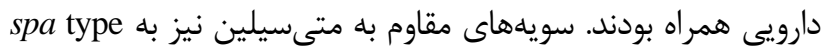
هاى t1814 و t386 تعلق يافتند كه بلترتيب از نمونههاى گوشت

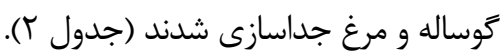

تيتهاى t14870 و t3802 از فراوانترين spa type هاى مشاهده شده در جدايههاى استافيلوكوكوس اورئوس بلدستآمده از نمونههاى

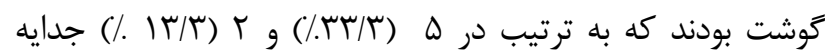

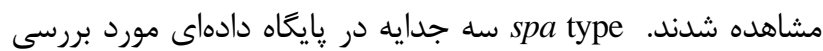
رديابى نشده و بهعنوان تيب هاى جديد در نظر گرفته شدند. همجنين از نظر توزيع تيڤهاى مولكولى در ميان نمونههاى كوشت مختلف،

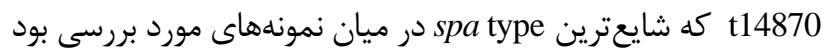

جدول r. رنوتيّ و الكوى حساسيت دارويى سويههاى /ستافيلوكوكوس /ورئوس جدا شده از نمونهاى كَشت

\begin{tabular}{|c|c|c|c|}
\hline الكوى مقاومت آنتىبيوتيكى & نوع نمونه كوشت & spa type & جدايه \\
\hline آميى سيلين، سييروفلو كساسين، لووفلوكساسين & 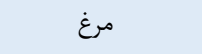 & $\mathrm{t} 14870$ & SA1 \\
\hline آميىسيلين & 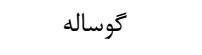 & New type & SA2 \\
\hline آميىسيلين & 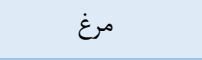 & t3802 & SA3 \\
\hline آميى سيلين، سفوكسيتين & كوساله & $\mathrm{t} 1814$ & SA4 \\
\hline آميىسيلين، سولفامتو كسازول-ترى متويريم، سيبروفلوكساسين، لووفلوكساسين & 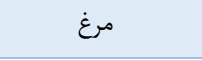 & $\mathrm{t} 14870$ & SA5 \\
\hline آمبىسيلين، سولفامتو كسازول-ترى متويريم، سييروفلوكساسين، لووفلوكساسين & 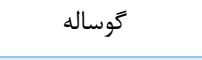 & $\mathrm{t} 14870$ & SA6 \\
\hline 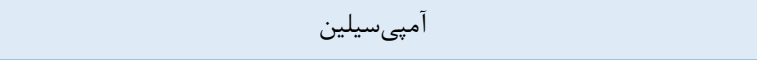 & 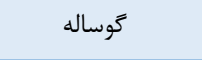 & $\mathrm{t} 491$ & SA7 \\
\hline آميىسيلين & 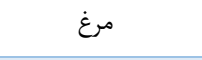 & New type & SA8 \\
\hline آميىسيلين & 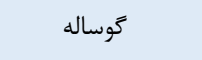 & $\mathrm{t} 3802$ & SA9 \\
\hline 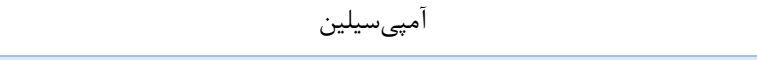 & 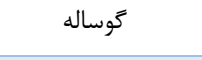 & New type & SA10 \\
\hline آمبىسيلين، سفوكسيتين & 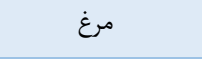 & $\mathrm{t} 386$ & SA11 \\
\hline 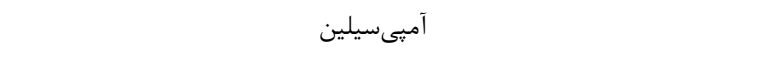 & 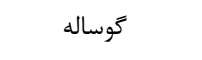 & $\mathrm{t} 14870$ & SA12 \\
\hline آميىسيلين & كوساله & $\begin{array}{c}\text { Non } \\
\text { typeable }\end{array}$ & SA13 \\
\hline آمبيىسيلين، سييروفلو كساسين، لووفلوكساسين & كوساله & $\mathrm{t} 3424$ & SA14 \\
\hline آميى سيلين، سولفامتو كسازول-ترى متويريم، سييروفلوكساسين، لووفلوكساسين & 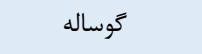 & $\mathrm{t} 14870$ & SA15 \\
\hline
\end{tabular}

انتقال سويههاى /شريشيا كلى مولد بتالاكتامازهاى وسيعالطيف از احشام به انسان از طريق زنجيرههاى غذايى وجود دارد (ه (1).

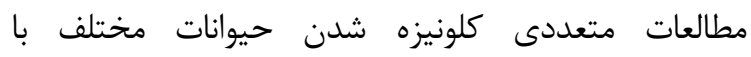
استافيلوكوكوس اورئوس را توصيف كردهاند و جدايههاى مقاوم به ميه متىسيلين نيز از حيوانات با كاربرد غذايى گزارش شدهاند (ع). سازمان بهداشت جهانى در سال MRSA r. IV را بهعنوان يكى از ז خانواده باكتريايى كه تهديد جدى براى سلامت انسان است

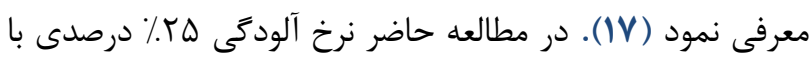

استفاده بى رويه و نادرست از آنتىبيوتيكهاى قلمرو يزشكى در كشاورزى بهعنوان محرك رشد يا بهعنوان عامل ييشگيرى كننده

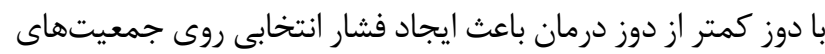
باكتريايى ساكن روده حيوانات و بروز مقاومت مىشود. اين گَونه باكترىهاى مقاوم مىتوانند بهطور مستقيم يا غير مستقيم از طريق

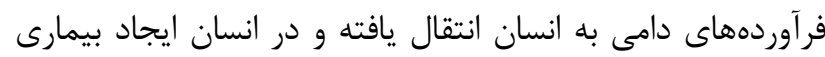

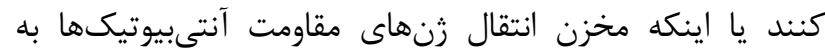

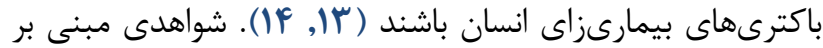


سويههاى /ستافيلوكوكوس اورئوس جدا شده از كوشت بهعنوان

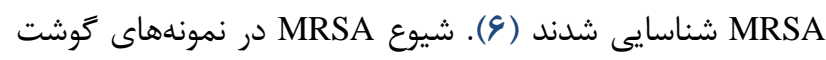

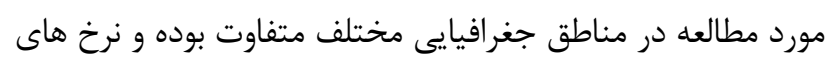

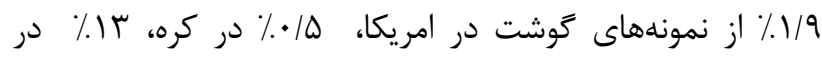

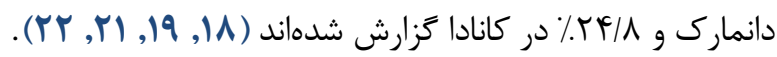
منشا جدايههاى باكتر يايى موجود در گَوشت مىتواند درونزاد

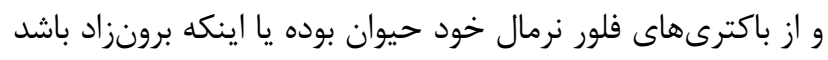

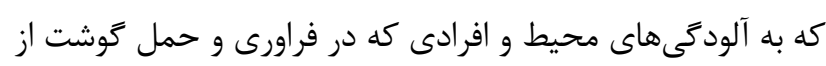

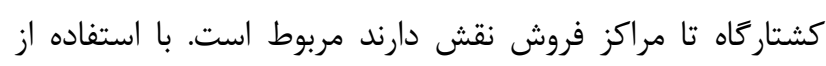

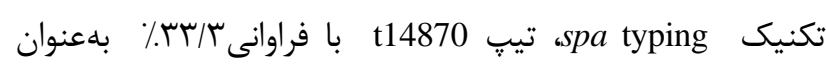
غالبترين spa type در جدايهماى /ستافيلوكوكوس اورئوس

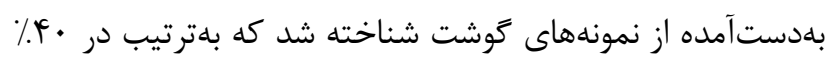

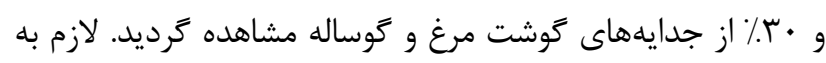

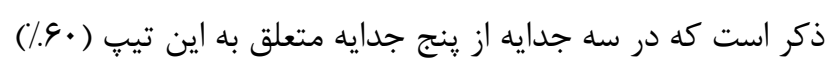

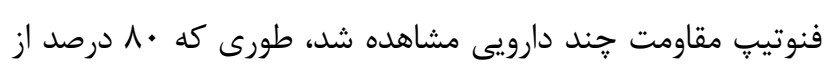

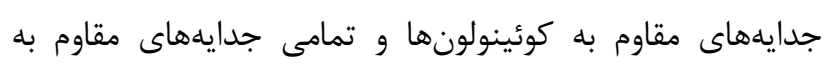

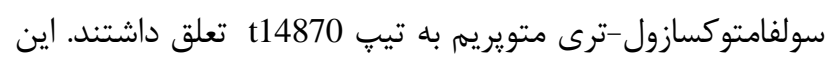

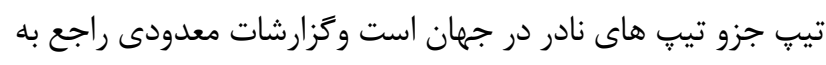

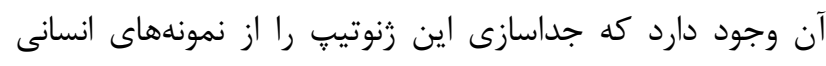

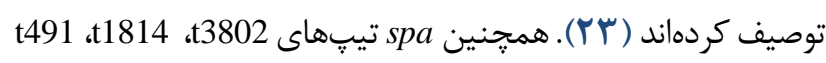

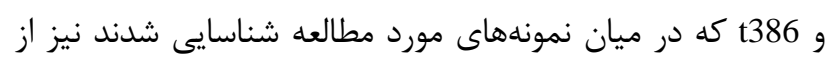

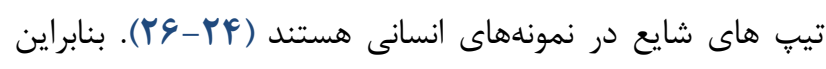

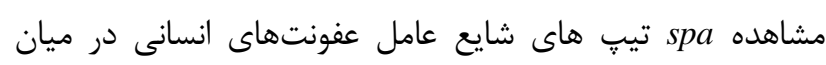

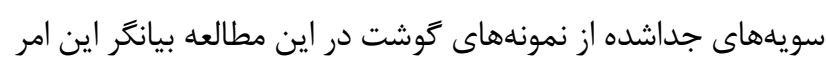

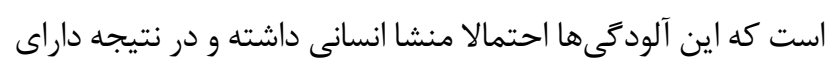

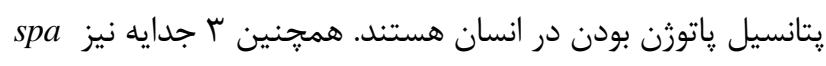

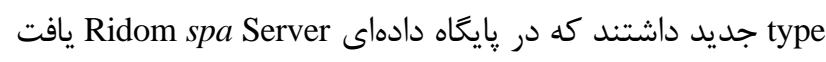

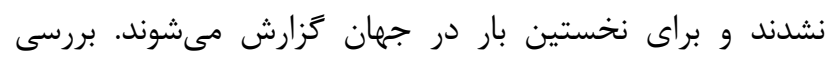

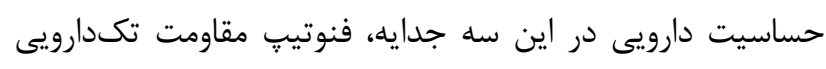

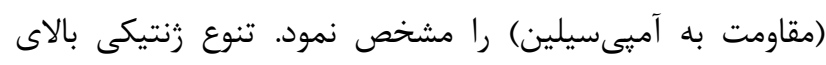

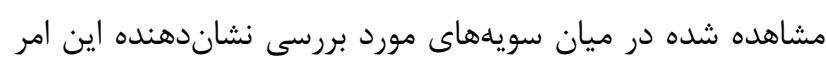

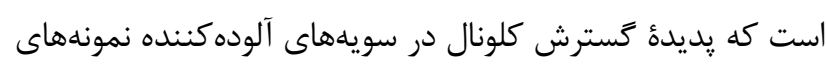

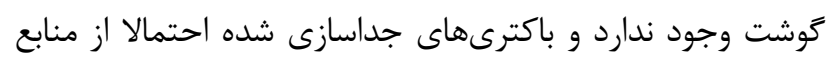

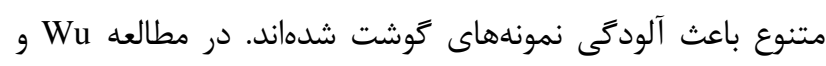

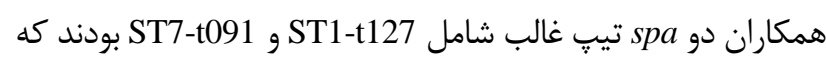

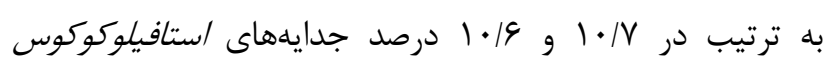

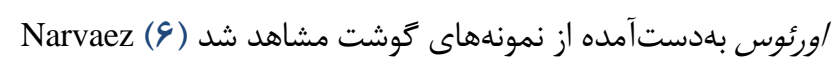

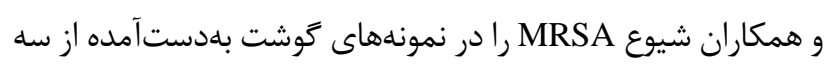

استافيلوكوكوس اورئوس (كوشت مرغ I/TV/V) كوشت كوساله

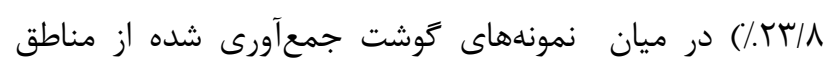

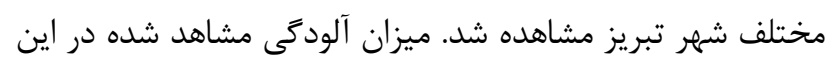

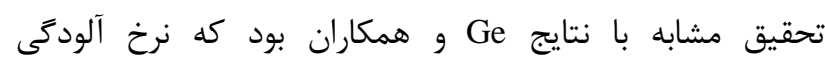

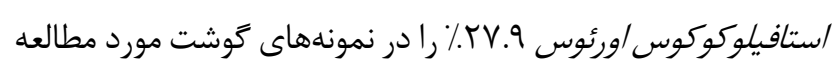

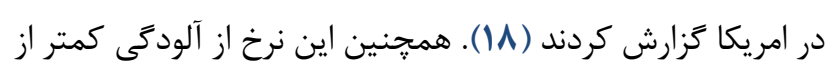

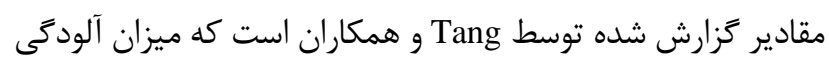

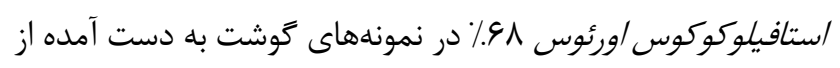

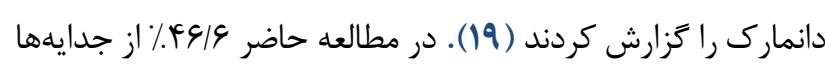

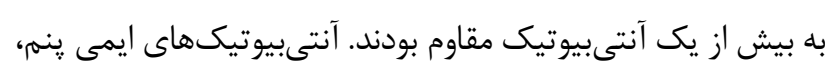

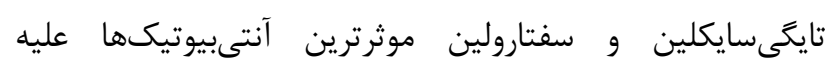

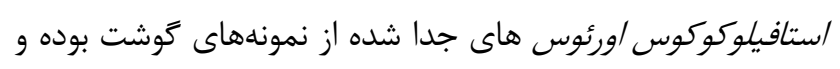

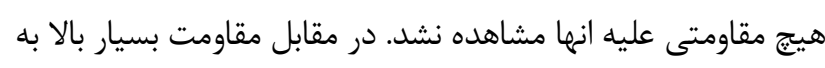

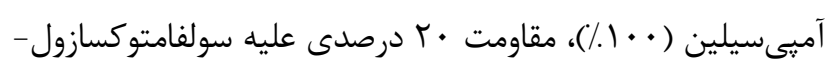

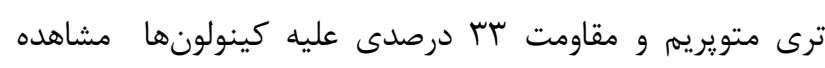

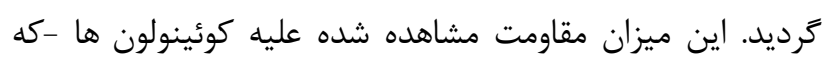

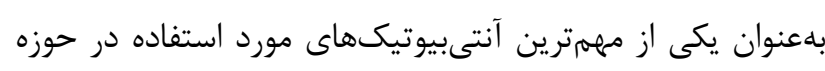
يزشكى براى درمان عفونتهاى ناحيه تنفسى فوقانى مانى و و ناحيه

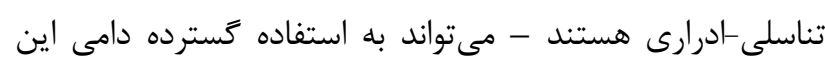

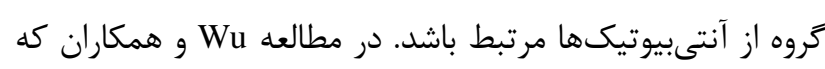

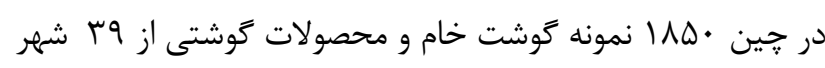

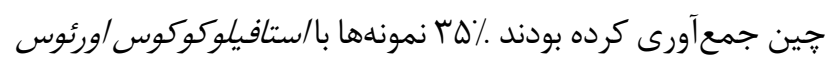

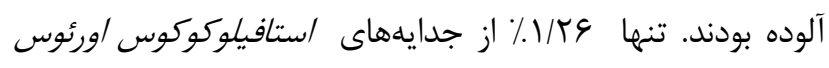

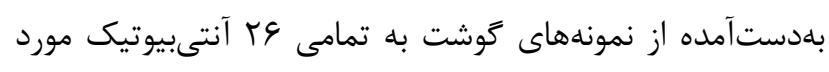

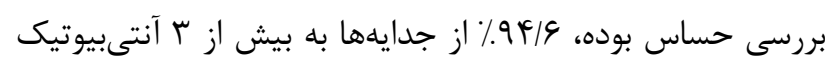

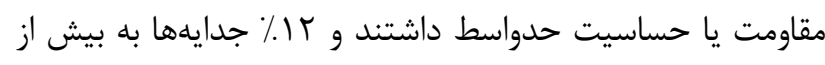

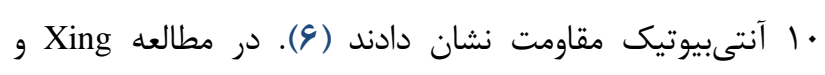

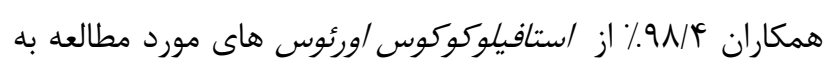

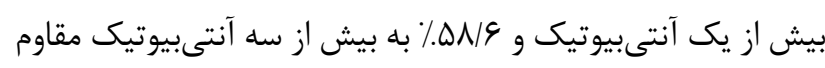

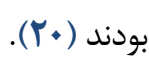

نكته حائز اهميت در تحقيق حاضر مشاهده باكترىهاى مقاوم

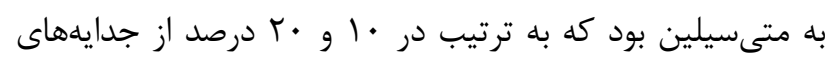

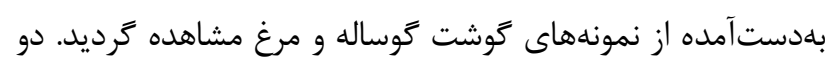

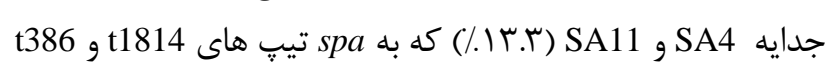

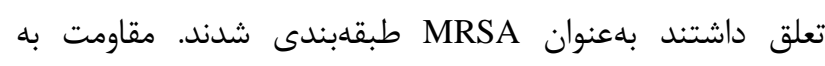
متىسيلين در اين دو سويه با هر دو روش فنوتيبيى و رنوتيبى تاييد

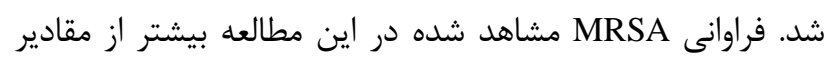

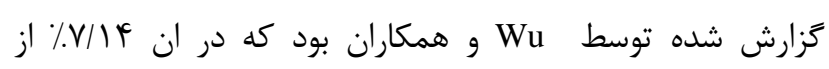




$$
\begin{aligned}
& \text { به اين آنتىبيوتيكها دخيل باشد. بنابراين بايد كنترل مناسبى بر }
\end{aligned}
$$

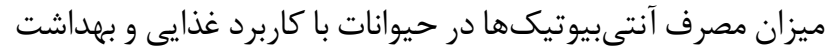

$$
\begin{aligned}
& \text { مواد غذايى در مراحل مختلف تهيه آنها از يرورش دام، كشتار كاه، } \\
& \text { بستهبندى و...... صورت گيرد تا از ييدايش و انتقال باكترىهاى } \\
& \text { مقاوم به آنتىبيوتيكها ممانعت شود. } \\
& \text { سياسگزارى }
\end{aligned}
$$$$
\text { مقاله حاضر از ياياننامه كارشناسى ارشد ميكروبيولوزى در }
$$

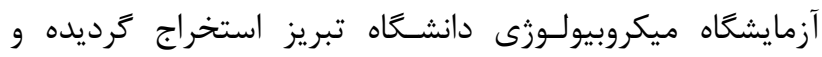$$
\text { بدينوسيله از حمايـت دانشـاه تبريـز تشكرو قدردانى مىشود. }
$$

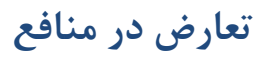

اين مقاله يزوهشى مستقل است كه بدون حمايت مالى

سازمانى انجام شده است. در انجام مطالعُ حاضر، نويسندكان ملان

$$
\text { هيجَونه تضاد منافعى نداشتهاند. }
$$

\section{Referance}

1. Kadariya J, Smith TC, Thapaliya D. Staphylococcus aureus and staphylococcal food-borne disease: an ongoing challenge in public health. BioMed research international. 2014;2014. [DOI:10.1155/2014/827965] [PMID] [PMCID]

2. Wei-Wei L, Zhu J, Zhen S, Liang X, Jiang Y, Ning L. Analysis of foodborne disease outbreaks in China mainland in 2011. Chin J Food Hygiene. 2018;30:283-8.

3. Jackson CR, Davis JA, Barrett JB. Prevalence and characterization of methicillin-resistant Staphylococcus aureus isolates from retail meat and humans in Georgia. Journal of clinical microbiology. 2013;51:1199-207. [DOI:10.1128/JCM.03166-12] [PMID] [PMCID]

4. McCallum N, Berger-Bächi B, Senn MM. Regulation of antibiotic resistance in Staphylococcus aureus. International Journal of Medical Microbiology. 2010;300:118-29. [DOI:10.1016/.ijmm.2009.08.015] [PMID]

5. Papadopoulos P, Papadopoulos T, Angelidis AS, Boukouvala E, Zdragas A, Papa A, et al. Prevalence of Staphylococcus aureus and of methicillin-resistant $\mathrm{S}$. aureus (MRSA) along the production chain of dairy products in north-western Greece. Food microbiology. 2018;69:43-50. [DOI:10.1016/j.fm.2017.07.016] [PMID]

6. Wu S, Huang J, Wu Q, Zhang J, Zhang F, Yang X, et al. Staphylococcus aureus isolated from retail meat and meat products in China: incidence, antibiotic resistance and genetic diversity. Frontiers in microbiology. 2018;9:2767. [DOI:10.3389/fmicb.2018.02767] [PMID] [PMCID]

$$
\begin{aligned}
& \text { كارخانه توليد كوشت خوك در كانادا بررسى نمودند. بر اساس نتايج } \\
& \text { آنها اغلب جدايههاى LA-MRSA به spa تيب هاى t034 و } \\
& \text { تعلق داشتند و مقاومت • ا درصدى به تايجى سايكلين و مقاومت }
\end{aligned}
$$

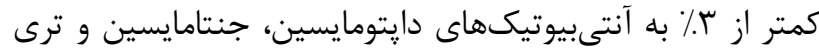

$$
\begin{aligned}
& \text { متويريم-سولفامتوكسازول مشاهده شد (YT). } \\
& \text { نتيجهَيرى } \\
& \text { در مجموع نتايج اين تحقيق نرخ آلودگى ه؟r٪ با } \\
& \text { /ستافيلوكوكوس /ورئوس را نشان داد و غالب تيب هاى مولكولى دانى } \\
& \text { مشاهده شده به عفونتهاى انسانى ارتباط داده شد. مشاهده }
\end{aligned}
$$

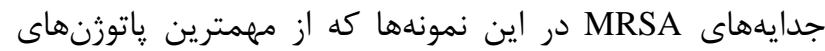

$$
\begin{aligned}
& \text { مطرح در يزشكى است بهعنوان يك خطر جدى براى بهداشت مواد }
\end{aligned}
$$

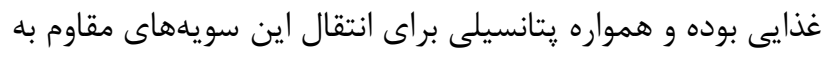

$$
\begin{aligned}
& \text { انسان از طريق زنجيره غذايى و انتشار آنها در جامعه وجود دارد. }
\end{aligned}
$$

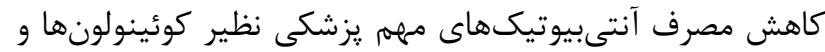

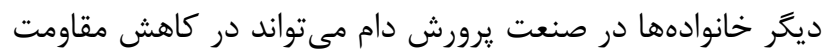

7. Voss A, Loeffen F, Bakker J, Klaassen C, Wulf M. Methicillin-resistant Staphylococcus aureus in pig farming. Emerging infectious diseases. 2005;11:1965. [DOI:10.3201/eid1112.050428] [PMID] [PMCID]

8. Kadlec K, Entorf M, Peters T. Occurrence and characteristics of livestock-associated methicillin-resistant Staphylococcus aureus in quarter milk samples from dairy cows in Germany. Frontiers in microbiology. 2019;10. [DOI:10.3389/fmicb.2019.01295] [PMID] [PMCID]

9. Wang X, Li G, Xia X, Yang B, Xi M, Meng J. Antimicrobial susceptibility and molecular typing of methicillin-resistant Staphylococcus aureus in retail foods in Shaanxi, China. Foodborne pathogens and disease. 2014;11:281-6. [DOI:10.1089/fpd.2013.1643] [PMID]

10. Koreen L, Ramaswamy SV, Graviss EA, Naidich S, Musser JM, Kreiswirth BN. spa typing method for discriminating among Staphylococcus aureus isolates: implications for use of a single marker to detect genetic micro-and macrovariation. Journal of clinical microbiology. 2004;42:792-9. [DOI:10.1128/JCM.42.2.792-799.2004] [PMID] [PMCID]

11. Strommenger B, Braulke C, Heuck D, Schmidt C, Pasemann B, Nübel U, et al. spa typing of Staphylococcus aureus as a frontline tool in epidemiological typing. Journal of clinical microbiology. 2008;46:574-81. [DOI:10.1128/JCM.01599-07] [PMID] [PMCID]

12. Patel JB. Performance standards for antimicrobial susceptibility testing: Clinical and Laboratory Standards Institute; 2017. 
13. Founou LL, Founou RC, Essack SY. Antibiotic resistance in the food chain: a developing country-perspective. Frontiers in microbiology. 2016;7:1881. [DOI:10.3389/fmicb.2016.01881] [PMID] [PMCID]

14. Chang Q, Wang W, Regev-Yochay G, Lipsitch M, Hanage WP. Antibiotics in agriculture and the risk to human health: how worried should we be? Evolutionary applications. 2015;8:240-7. [DOI:10.1111/eva.12185] [PMID] [PMCID]

15. Kluytmans JA, Overdevest IT, Willemsen I, KluytmansVan Den Bergh MF, Van Der Zwaluw K, Heck M, et al. Extended-spectrum $\beta$-lactamase-producing Escherichia coli from retail chicken meat and humans: comparison of strains, plasmids, resistance genes, and virulence factors. Clinical Infectious Diseases. 2012;56:478-87. [DOI:10.1093/cid/cis929] [PMID]

16. Gharsa H, Slama KB, Lozano C, Gómez-Sanz E, Klibi N, Sallem RB, et al. Prevalence, antibiotic resistance, virulence traits and genetic lineages of Staphylococcus aureus in healthy sheep in Tunisia. Veterinary microbiology.

[DOI:10.1016/j.vetmic.2011.11.009] [PMID]

17. Asokan GV, Vanitha A. WHO global priority pathogens list on antibiotic resistance: an urgent need for action to integrate one health data. Perspectives in public health. 2018;138:87-8. [DOI:10.1177/1757913917743881] [PMID]

18. Ge B, Mukherjee S, Hsu C-H, Davis JA, Tran TTT, Yang Q, et al. MRSA and multidrug-resistant Staphylococcus aureus in US retail meats, 2010-2011. Food microbiology. 2017;62:289-97. [DOI:10.1016/j.fm.2016.10.029] [PMID]

19. Tang Y, Larsen J, Kjeldgaard J, Andersen PS, Skov R, Ingmer H. Methicillin-resistant and-susceptible Staphylococcus aureus from retail meat in Denmark. International journal of food microbiology. 2017;249:726. [DOI:10.1016/j.ijfoodmicro.2017.03.001] [PMID]

20. Xing X, Li G, Zhang W, Wang X, Xia X, Yang B, et al. Prevalence, antimicrobial susceptibility, and enterotoxin gene detection of Staphylococcus aureus isolates in readyto-eat foods in Shaanxi, People's Republic of China. Journal of food protection. 2014;77:331-4. [DOI:10.4315/0362-028X.JFP-13-301] [PMID]

21. Kim YJ, Oh DH, Song BR, Heo EJ, Lim JS, Moon JS, et al. Molecular characterization, antibiotic resistance, and virulence factors of methicillin-resistant Staphylococcus aureus strains isolated from imported and domestic meat in Korea. Foodborne pathogens and disease. 2015;12:3908. [DOI:10.1089/fpd.2014.1885] [PMID]

22. Narvaez-Bravo C, Toufeer M, Weese S, Diarra M, Deckert A, Reid-Smith R, et al. Prevalence of methicillinresistant Staphylococcus aureus in Canadian commercial pork processing plants. Journal of applied microbiology. 2016;120:770-80. [DOI:10.1111/jam.13024] [PMID]
23. Alni RH, Mohammadzadeh A, Mahmoodi P. Molecular typing of Staphylococcus aureus of different origins based on the polymorphism of the spa gene: characterization of a novel spa type. 3 Biotech. 2018;8:58. [DOI:10.1007/s13205-017-1061-6] [PMID] [PMCID]

24. Abbasian S, Farahani NN, Mir Z, Alinejad F, Haeili M, Dahmardehei $\mathrm{M}$, et al. Genotypic characterization of Staphylococcus aureus isolated from a burn centre by using agr, spa and SCCmec typing methods. New microbes and new infections. 2018;26:15-9. [DOI:10.1016/j.nmni.2018.08.001] [PMID] [PMCID]

25. Rijnders M, Deurenberg R, Boumans M, HoogkampKorstanje J, Beisser P, Stobberingh E. Population structure of Staphylococcus aureus strains isolated from intensive care unit patients in the Netherlands over an 11year period (1996 to 2006). Journal of clinical microbiology. 2009;47:4090-5 [DOI:10.1128/JCM.00820-09] [PMID] [PMCID]

26. Hashemizadeh Z, Hadi N, Mohebi S, KalantarNeyestanaki D, Bazargani A. Characterization of SCCmec, spa types and Multi Drug Resistant of methicillin-resistant Staphylococcus aureus isolates among inpatients and outpatients in a referral hospital in Shiraz, Iran. BMC research notes. 2019;12:614. [DOI:10.1186/s13104-019-4627-z] [PMID] [PMCID] 